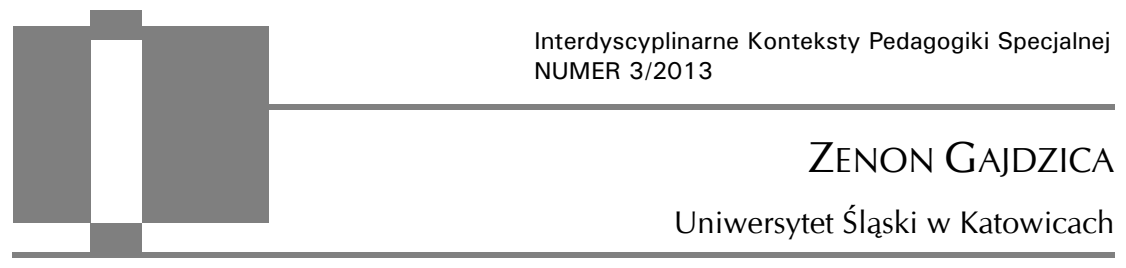

\title{
O roli i pozycji badacza w badaniach rzeczywistości szkoły specjalnej i integracyjnej
}

\begin{abstract}
Gajdzica Zenon, On the role and rank of a researcher in the studies into the reality of special and integrated school [O roli i pozycji badacza w badaniach rzeczywistości szkoły specjalnej i integracyjnej]. Interdyscyplinarne Konteksty Pedagogiki Specjalnej, nr 3, Poznań 2013. Pp. 9-19. Adam Mickiewicz University Press. ISBN 978-83-232-2721-2. ISSN 2300-391X.

What the study presents is an authorial concept of one of the possible typologies of the research into special education (in special, integrated and mainstream school). The starting point of this typology is the role and rank of the researcher (actor observer) applied in various research concepts. In the further part, this is juxtaposed with the studies based on direct and indirect data collection. The essence of the text is an analysis of trendy and infrequent types of studies in the indicated field. This analysis incidentally refers to the correctness of the conducted explorations. The study is completed with final conclusions, which comprise a short list of the neglected issues in the field of special education.
\end{abstract}

KEY WORDS: special education, researcher's role, research concept

\section{Wprowadzenie}

Kształcenie uczniów niepełnosprawnych w ciągu ostatnich kilkunastu lat podlega nieustannej, wielozakresowej transformacji. Obejmuje ona: zmianę ustroju szkolnego, gruntownie przebudowa- 
ną w 1999 r., przeobrażenia organizacyjne i jakościowe w orzekaniu o potrzebie kształcenia specjalnego oraz specjalnych potrzeb edukacyjnych, bezustanne przemiany w zakresie sieci szkół specjalnych i integracyjnych, statystyczne zmiany dotyczące realizacji obowiązku szkolnego uczniów niepełnosprawnych w określonych formach kształcenia (separacyjnego, integracyjnego, włączającego), nieustannie toczącą się reformę programową. Zapewne, prócz wskazanych, można by wymienić jeszcze kilka mniej lub bardziej znaczących tendencji i obszarów reformowania. Część wymienionych zmian jest następstwem naturalnego przeobrażania oczekiwań wobec szkoły (specjalnej, integracyjnej, ogólnodostępnej) - jej struktury, funkcji i projektowanych dla niej społecznie zadań, przeobrażeń społecznych (np. zmiany postaw społecznych wobec niepełnosprawności, także postaw rodziców uczniów niepełnosprawnych), rozwoju pedagogiki (w jej obszarze także pedagogiki specjalnej) oraz nauk pokrewnych, przemian ekonomicznych i, wreszcie, pojawiających się ideologii politycznych. Część przeobrażeń jest więc logicznym i zarazem naturalnym następstwem ogólnych zmian społecznych. Inne powodowane są ambicjami poszczególnych ekip rządowych, czasem wymuszane próbą oszczędności lub innymi - nie do końca opartymi na przejrzystych przesłankach - przyczynami.

W opracowaniu pomijam kwestie samej istoty zmian edukacyjnych w obszarze kształcenia uczniów niepełnosprawnych (chociaż stanowią one istotny kontekst wywodu), koncentrując się na typach badań szkoły. Przyczynkiem do ich analizy jest rola i pozycja badacza, generalnie rzadko akcentowana $\mathrm{w}$ analizach badań na gruncie pedagogiki specjalnej.

Artykuł składa się z kilku części. Punktem wyjścia jest prezentacja autorskiej, jednej z możliwych, typologii badań rzeczywistości szkolnej dokonana na kanwie zaakcentowanej wcześniej pozycji i roli badacza. Meritum tekstu stanowi nieco powierzchowna (ze względu na ograniczone ramy opracowania) analiza modnych i pomijanych typów badań we wskazanym obszarze, incydentalnie nawiązująca do poprawności prowadzonych eksploracji. Całość zamykają konkluzje. 


\section{Rola i pozycja badacza w eksploracji rzeczywistości szkoły specjalnej i integracyjnej}

W konstrukcji przyjętej typologii opieram się na kilku zmiennych. Punktem wyjścia jest rola i pozycja badacza wobec badanego obiektu. W dalszej części zostaje ona odniesiona do poznania pośredniego i bezpośredniego.

Rola, jaką badacz przyjmuje $\mathrm{w}$ realizowanym projekcie, jest szczególnym przedmiotem zainteresowania antropologów kulturowych i etnologów, co nie może dziwić - wszak poznanie i wyjaśnienie danej kultury wymaga wielu zabiegów nierzadko związanych $\mathrm{z}$ koniecznością wtopienia się $\mathrm{w}$ określone pole badawcze, nie tracąc jednocześnie szerszej perspektywy oglądu badanego środowiska ${ }^{1}$. Najprościej rzecz ujmując, rola ta może być związana z byciem aktorem badanego wycinak rzeczywistości bądź jego obserwatorem. Pod pojęciem obserwatora $\mathrm{w}$ tym ujęciu rozumiem „zbieracza danych" przy użyciu różnych technik, ale nie zaangażowanego w zmianę badanego obiektu.

Jak zauważa Barbara Czarniawska, obserwator „nigdy nie będzie miał lepszej wiedzy niż aktorzy, cudzoziemiec nigdy nie pojmie lepiej tubylczej kultury niż tubylcy, ale obserwator i cudzoziemiec mogą mieć inny obraz działania czy kultury niż aktorzy i tubylcy"2.

Przyjęcie tego stanowiska łączy się z założeniem, że opisanie, zrozumienie i wyjaśnienie badanego wycinka rzeczywistości możliwe jest nie tylko $\mathrm{w}$ związku $\mathrm{z}$ byciem $\mathrm{w}$ badanym świecie, ale także w związku z aktywnym jego zmienianiem. Rola taka musi łączyć się $\mathrm{z}$ zaangażowaniem emocjonalnym badacza $\mathrm{w}$ postrzeganie badanej rzeczywistości. Naturalnie emocje badacza tworzą wówczas kontekst obserwowanych zjawisk, nie należy ich traktować jako

${ }^{1}$ Np. T.H. Eriksen, Mate miejsca, wielkie sprawy. Wprowadzenie do antropologii społecznej i kulturowej, Oficyna Wydawnicza Volumen, Warszawa 2009, s. 36.

2 B. Czarniawska, Nowe techniki badań terenowych: shadowning, [w:] D. Jemielniak (red.), Badania jakościowe. Metody i narzędzia, t. 2, Wyd. Nauk. PWN, Warszawa 2012, s. 73 . 
danych empirycznych, mogą jednak być użytecznym narzędziem analitycznym ${ }^{3}$. W każdym razie współuczestniczenie $\mathrm{w}$ procesach i współbycie $w$ opisywanych oraz wyjaśnianych stanach, zgodnie z tym założeniem, pozwala lepiej zrozumieć badany obiekt $\mathrm{i}$ jego kontekst.

$\mathrm{Z}$ drugiej strony - uczestnictwo i zaangażowane działanie mogą zamazywać, a nawet zniekształcać badaną rzeczywistość. Mogą również sprzyjać niedostrzeganiu (pomijaniu) niektórych istotnych kontekstów, co wyraźnie akcentuje Michaił Bachtin, twierdząc: „Aby zrozumieć, jest niesłychanie ważne, aby, osoba, która stara się zrozumieć, była umiejscowiona na zewnątrz przedmiotu jej twórczego zrozumienia - $\mathrm{w}$ innym czasie, przestrzeni, kulturze. Człowiek nie może zobaczyć samego siebie z zewnątrz, przynajmniej nie w całości - nie pomogą tu ani lustra, ani fotografie. Tylko inni ludzie mogą przeżyć $w$ pełni wartość mojego ciała zewnętrznego, dlatego że są umiejscowieni na zewnątrz mnie i dlatego że są inni" ${ }^{4}$. Podobny pogląd wyraża Hannah Arendt, podkreślając, że jedynie obserwator, nigdy zaś aktor, może zrozumieć i wiedzieć, co dokonuje się $\mathrm{w}$ widowisku. Prawdę spektaklu można więc zrozumieć jedynie za cenę wycofania się z tego, co się dzieje ${ }^{5}$.

Trudno nie uznać tego poglądu za równie zasadnego. Nie sposób zatem rozstrzygać, które podejście wydaje się generalnie trafniejsze $\mathrm{w}$ badaniu rzeczywistości szkolnej. Bez wątpienia trafność przyjętej roli zależy od celów badań, przedmiotu eksploracji i ogólnego projektu badawczego.

Przywołany podział na aktora i obserwatora, chociaż ściśle związany z pozycją badacza wobec obiektu badanego, umożliwia jednak pewne wariancje. Otóż bycie aktorem faktycznie wymusza

${ }^{3}$ K. Konecki, Studia z metodologii badań jakościowych. Teoria ugruntowana, Wyd. Nauk. PWN, Warszawa 2000, s. 155.

4 Za: B. Czarniawska, dz. cyt., s. 73.

${ }^{5}$ H. Arendt, Myślenie, Wyd. „Czytelnik”, Warszawa 1991; podaję za: P. Dehnel, Poznanie a społeczny świat życia, [w:] M. Dziemianowicz, B.D. Gołębniak, R. Kwaśnica (red.), Przetrwanie i rozwój jako niezbywalne powinności wychowania, Wyd. Nauk. Dolnośląskiej Szkoły Wyższej Edukacji TWP we Wrocławiu, Wrocław 2005, s. 19. 
pozycję wewnątrz badanego świata. Bycie wewnątrz może wiązać się z autoobserwacją (prowadzonych badań dotyczących samego siebie) i/lub koncentrować się na rozpoznawaniu oraz wyjaśnianiu otaczającej aktora rzeczywistości ze szczególnym uwzględnieniem kontekstualności i roli pozostałych aktorów. Z kolei rola obserwatora może, ale nie musi łączyć się z pozycją wewnątrz. Wszak obserwator może być uczestnikiem badanego świata, ale nie odgrywać w nim roli wpływającej na obiekt badań. Przykładem jest obserwacja uczestnicząca (niejawna) z zastosowaniem techniki cienia ${ }^{6}$ czy wcielenie się w rolę dowolnego członka personelu DPS (biernego w swoich obowiązkach w relacji do badanego obiektu7) lub szkoły. Wówczas badacz uczestniczy w świecie, ale nie odgrywa w nim żadnej istotnej roli, nie determinuje zachowań (przynajmniej w założeniach) badanego obiektu. Inaczej ujmując, nie zmienia badanej rzeczywistości. Obserwator może także znajdować się w świecie, zachowywać się biernie, ale w sposób nieskrywany (typowa obserwacja jawna). Przykładem tego są klasyczne obserwacje lekcji będące podstawą wielu badań w tradycyjnej dydaktyce specjalnej. Problem jednak w tym, że wówczas obserwowana rzeczywistość (w omawianym przypadku lekcja) traci walory naturalności i staje się sztucznym przedstawieniem odgrywanym na potrzeby wcześniej zapowiedzianego obserwatora. Niemniej jednak $\mathrm{i}$ ta technika w przeszłości sprzyjała nierzadko identyfikowaniu i demaskowaniu wielu problemów szkolnych. Wreszcie badacz może spoglądać na szkołę z perspektywy szerszej, na przykład analizując dane szkolne obwodowych komisji egzaminacyjnych ${ }^{8}$, badać sposoby pracy szkoły na podstawie analizy protokołów obserwacji sporządzonych

${ }^{6}$ B. Czarniawska, dz. cyt., s. 73.

7 Zob. J. Niedbalski, Krótki epizod przynależności - „nowy”, „normalny”, „nieznany" wśród osób z upośledzeniem umysłowym. Problematyka tożsamości badacza w procesie eksploracji terenowej badanego środowiska, [w:] K. Konecki, A. Kasperczyk (red.), Procesy tożsamościowe. Symboliczno-interakcyjny wymiar konstruowania ładu i nieładu społecznego, Wyd. UŁ, Łódź 2010, s. 45-62.

${ }^{8}$ I. Chrzanowska, Zaniedbane obszary edukacji - pomiędzy pedagogika a pedagogika specjalna. Wybrane zagadnienia, Oficyna Wydawnicza „Impuls”, Kraków 2009. 
przez innych badaczy ${ }^{9}$, diagnozować efekty edukacji na podstawie wyników specjalnie do tego celu przeprowadzonych testów ${ }^{10}$, wytworów uczniów, pamiętników nauczycieli czy zapisanych uwag w dziennikach. Możliwym rozwiązaniem, bodajże najczęściej stosowanym w obecnych (także dawnych) badaniach, jest zbieranie opinii (deklaracji) na temat funkcjonowania szkoły za pomocą kwestionariuszy, ankiet czy wywiadu.

Uogólniony schemat przedstawionych możliwości zamieszczono $\mathrm{w}$ tabeli 1.

Tabela 1. Pozycja i rola badacza w poznaniu rzeczywistości szkolnej

\begin{tabular}{|c|c|c|}
\hline Rola & Pozycja & Relacja z obiektem \\
\hline \multirow[b]{2}{*}{$\begin{array}{l}\text { Aktor/badacz/(osoba } \\
\text { uczestnicząca - działająca) }\end{array}$} & $\begin{array}{l}\text { w badanym świecie } \\
\text { - obiekt }\end{array}$ & autoobserwator \\
\hline & \multirow{2}{*}{$\begin{array}{l}\text { w badanym świecie } \\
\text { - poza obiektem }\end{array}$} & $\begin{array}{l}\text { obserwator zaangażowany } \\
\text { (działający na obiekt badań } \\
\text { - w relacji z obiektem) }\end{array}$ \\
\hline \multirow{3}{*}{$\begin{array}{l}\text { Badacz/obserwator/(osoba } \\
\text { postrzegająca rzeczywistość } \\
\text { bezpośrednio i pośrednio) }\end{array}$} & & $\begin{array}{l}\text { obserwator wewnętrzny } \\
\text { (bez wpływu na obiekt) }\end{array}$ \\
\hline & \multirow[b]{2}{*}{$\begin{array}{l}\text { poza badanym światem } \\
\text { lub na jego marginesie }\end{array}$} & $\begin{array}{l}\text { obserwator zewnętrzny } \\
\text { (jawny, ukryty) }\end{array}$ \\
\hline & & $\begin{array}{l}\text { obserwator pośredni (ana- } \\
\text { lizujący dane zapisane, np. } \\
\text { film) }\end{array}$ \\
\hline
\end{tabular}

Inną kwestią, zasygnalizowaną wyżej, jest typ poznania - bezpośredni i pośredni. Aktor podczas obserwacji etnograficznej postrzega badany obiekt w sposób bezpośredni, nieustannie uczestnicząc i zmieniając badany świat. Badacz również bezpośrednio może

${ }_{9}$ Z. Gajdzica, Podręcznik w procesie ksztatcenia uczniów z lekkim upośledzeniem umystowym, Wyd. UŚ, Katowice 2002.

${ }^{10}$ G. Szumski, A. Firkowska-Mankiewicz (współprac.), Wokót edukacji włączajacej. Efekty kształcenia uczniów z niepetnosprawnościa intelektualna w stopniu lekkim w klasach specjalnych, integracyjnych i ogólnodostępnych, Wyd. APS, Warszawa 2010. 
zbierać dane, postrzegając badaną rzeczywistość podczas obserwacji, na przykład etnograficznej lub innego typu. Może też korzystać z opinii innych osób, poznając badany obiekt pośrednio. Uproszczony schemat takich możliwości został przedstawiony w tabeli 2 .

Tabela 2. Cel badań, typ poznania a dystans do badanego obiektu

\begin{tabular}{|l|l|l|}
\hline \multicolumn{1}{|c|}{ Cel } & \multicolumn{1}{|c|}{ Poznanie } & \multicolumn{1}{c|}{ Dystans do obiektu } \\
\hline $\begin{array}{l}\text { Badanie zdarzeń, pro- } \\
\text { cesów, własności, sta- } \\
\text { nów }\end{array}$ & bezpośrednie & poznanie obiektu (kontakt z obiektem) \\
\cline { 1 - 2 } $\begin{array}{l}\text { Badanie opinii o zda- } \\
\text { rzeniach, procesach, } \\
\text { własnościach, stanach }\end{array}$ & pośrednie & $\begin{array}{l}\text { poznanie informacji o obiekcie (kon- } \\
\text { takt ze źródłem informacji o obiekcie) }\end{array}$ \\
& & $\begin{array}{l}\text { poznanie opinii o obiekcie (kontakt ze } \\
\text { źródłem informacji o opinii) }\end{array}$ \\
\hline
\end{tabular}

Sposób poznania powinien ściśle wiązać się także z celem badania oraz założeniem poznania rzeczywistości lub opinii o niej (poglądów na jej temat, deklaracji itp.). W tej kwestii warto zwrócić uwagę na możliwe błędy. Przede wszystkim należy jasno rozróżnić badanie rzeczywistości od badania opinii o niej. Trudno zaakceptować poprawność projektu badawczego osadzonego w paradygmacie pozytywistycznym, którego główną (często jedyną) metodą zbierania danych jest sondaż diagnostyczny zakładający poznanie bezpośrednie badanego obiektu bez założenia, że respondenci udzielają odpowiedzi subiektywnych, czyli de facto takich, ,jak im się wydaje, że jest"11. Przyjęcie tego modelu jest natomiast możliwe $\mathrm{w}$ koncepcjach relatywistycznych przy założeniu, że świat jest taki, jak widzi go respondent, a jego obraz jest jednym z możliwych konstruktów rzeczywistości szkolnej. Inaczej ujmując, wymaga założenia istnienia różnych rzeczywistości w zależności od tego, jak widzą

${ }^{11}$ Kwestionariusze ankiet czy wywiadów zwykle zawierają pytania o charakterze interpretacyjnym, dającym respondentowi możliwość „pływania” między kategoriami. Por. H. Schuman, Metoda i znaczenie w badaniach sondażowych, Oficyna Naukowa, Warszawa 2013. 
je badani ${ }^{12}$. To jednak wymaga założenia opisu i wyjaśnienia z przyjęciem narracji „w opinii...”.

Nie sposób jednak oprzeć się wrażeniu, że większość tradycyjnych badań nad rzeczywistością szkolną w obszarze pedagogiki specjalnej zasadza się na wskazanym błędzie łączenia zasad epistemologii empirycznej osadzonej w pozytywizmie ze zbieraniem danych pośrednich (szczególnie $\mathrm{z}$ wykorzystywaniem narzędzi niewystandaryzowanych) i traktowaniu ich jako obiektywnego źródła wiedzy o przedmiocie badań.

Inaczej - w moim przekonaniu - należy ocenić koncepcje badania pośredniego z wykorzystywaniem narzędzi wystandaryzowanych lub analizujące dane pośrednie zebrane w wyniku konkretnych analiz systemowych (np. dane statystyczne o formie kształcenia czy wyniki egzaminów końcowych), oczywiście pod warunkiem, że sam przedmiot badań nie dotyczy opinii, ale konkretnego stanu poddanego zobiektywizowanemu pomiarowi.

\section{Konkluzje}

Spoglądając subiektywnie na powszechnie dostępne (wydane drukiem w formie autorskiej pozycji zwartej) projekty badania rzeczywistości szkolnej, realizowane $\mathrm{w}$ ostatnich latach $\mathrm{w}$ pedagogice specjalnej, przede wszystkim nie sposób oprzeć się wrażeniu, że jest ich niewiele. Sądzę, że można nawet sformułować tezę, iż należą one do wątków marginalizowanych w kontekście wielu nowatorskich koncepcji badań nad społeczną sytuacją osób z niepełnosprawnością. Trudno w związku z tym o wskazanie obszarów szczególnie dobrze eksploatowanych w zakresie diagnozy i prób wyjaśniania okoliczności kształcenia instytucjonalnego. W aspekcie przywołanych we wstępie niezwykle intensywnych zmian ustroju szkolnego i uwarunkowań edukacji szkolnej można uznać to za

12 P.L. Berger, T. Luckmann, Społeczne tworzenie rzeczywistości, Wyd. Nauk. PWN, Warszawa 2010, s. 251. 
zaskakujące. Być może jest to efekt stosunkowo silnego zainteresowania pedagogiki specjalnej szkołą w latach 70. i 80. ubiegłego wie$\mathrm{ku}$, co z jednej strony wyczerpało tę problematykę, a z drugiej doprowadziło do zaniedbań poznawania obszaru środowiska pozaszkolnego. Inną przyczyną mogą być wskazane wyżej dyskusyjne metody zbierania danych oraz ich traktowania jako obiektywne źródło informacji o rzeczywistości szkolnej. W rezultacie mogło się to spotkać z konstruktywną krytyką recenzentów, na przykład $\mathrm{w}$ przypadku prac awansowych, i w rezultacie zniechęciło wielu badaczy do podejmowania tego typu eksploracji. Wreszcie warto wspomnieć, że szczególnie dydaktyka (także specjalna) przez wiele lat skutecznie opierała się wyjściu poza strukturalne i funkcjonalne sposoby rozpatrywania procesów edukacji, to zaś postawiło ją w sytuacji zapóźnienia paradygmatycznego w relacji do innych subdyscyplin pedagogicznych. Naturalnie zdaję sobie sprawę, że wskazane przyczyny są raczej zbiorem presumpcji opartych na wybranych przesłankach aniżeli stwierdzeniem faktu, nie zmienia to jednak obecnego stanu zaniedbania omawianego obszaru.

Wskazując zaniedbane obszary badań nad edukacją specjalną (pod jej pojęciem mam na myśli wszystkie formy kształcenia uczniów z orzeczoną potrzebą kształcenia specjalnego, także w szkołach/klasach integracyjnych oraz ogólnodostępnych) w zakresie merytorycznym warto wspomnieć między innymi o:

- problematyce przeobrażeń sieci placówek kształcenia specjalnego i integracyjnego, zwłaszcza w aspekcie licznych zmian związanych z likwidacją (zawieszaniem działalności) szkół specjalnych, z uwzględnieniem długości dojazdu uczniów niepełnosprawnych do szkoły oraz przemian demograficznych na terenach wiejskich i miejskich, a także faktycznego finansowania (wykorzystywania dotacji celowej) omawianej grupy uczniów;

- uwarunkowaniach skuteczności realizacji celów kształcenia, między innymi stosowanych metod kształcenia, wykorzystywanych środków dydaktycznych, zwłaszcza w kształceniu integracyjnym i inkluzyjnym; 
- kompetencjach nauczycieli uzyskujących w różnych formach kształcenia i dokształcania kwalifikacje z zakresu pedagogiki specjalnej.

Z kolei spoglądając na problematykę badań w aspekcie samych koncepcji badawczych, zwłaszcza ulokowanych wewnątrz szkoły, do rzadko realizowanych należą badania $\mathrm{z}$ zastosowaniem metod etnograficznych. Brakuje szerszego oglądu funkcjonowania kształcenia specjalnego rozpatrywanego na gruncie konstruktywizmu, fenomenologii czy hermeneutyki w związku z ciągle dominującymi paradygmatami osadzonymi w nurcie strukturalno-funkcjonalnym.

Mimo że sformułowana lista przyjmuje postać jedynie powierzchownego i uproszczonego zestawiania, żywię jednak nadzieję, że może ono stanowić punkt wyjścia do głębszej refleksji nad wieloparadygmatycznym i wielozakresowym badaniem rzeczywistości szkolnej w placówkach prowadzących edukację uczniów z orzeczoną potrzebą kształcenia specjalnego.

\section{Bibliografia}

ARENDT H., Myślenie, Wyd. „Czytelnik”, Warszawa 1991.

BERGER P.L., LUCKMANN T., Społeczne tworzenie rzeczywistości, Wyd. Nauk. PWN, Warszawa 2010.

CHRZANOWSKA I., Zaniedbane obszary edukacji - pomiędzy pedagogika a pedagogika specjalna. Wybrane zagadnienia, Oficyna Wydawnicza „Impuls”, Kraków 2009.

CZARNIAWSKA B., Nowe techniki badań terenowych: shadowning, [w:] D. Jemielniak (red.), Badania jakościowe. Metody i narzędzia, t. 2, Wyd. Nauk. PWN, Warszawa 2012.

DEHNEL P., Poznanie a społeczny świat życia, [w:] M. Dziemianowicz, B.D. Gołębniak, R. Kwaśnica (red.), Przetrwanie i rozwój jako niezbywalne powinności wychowania, Wyd. Nauk. Dolnośląskiej Szkoły Wyższej Edukacji TWP we Wrocławiu, Wrocław 2005.

ERIKSEN T.H., Małe miejsca, wielkie sprawy. Wprowadzenie do antropologii społecznej i kulturowej, Oficyna Wydawnicza Volumen, Warszawa 2009.

GAJDZICA Z., Podręcznik w procesie ksztatcenia uczniów z lekkim upośledzeniem umysłowym, Wyd. UŚ, Katowice 2002.

KONECKI K., Studia z metodologii badań jakościowych. Teoria ugruntowana, Wyd. Nauk. PWN, Warszawa 2000. 
NIEDBALSKI J., Krótki epizod przynależności - „nowy”, „normalny”, „nieznany” wśród osób z upośledzeniem umystowym. Problematyka tożsamości badacza w procesie eksploracji terenowej badanego środowiska, [w:] K. Konecki, A. Kasperczyk (red.), Procesy tożsamościowe. Symboliczno-interakcyjny wymiar konstruowania tadu i nieładu społecznego, Wyd. UŁ, Łódź 2010.

SCHUMAN H., Metoda i znaczenie w badaniach sondażowych, Oficyna Naukowa, Warszawa 2013.

SZUMSKI G., FIRKOWSKA-MANKIEWICZ A. (współprac.), Wokót edukacji wtączającej. Efekty kształcenia uczniów z niepetnosprawnościa intelektualna w stopniu lekkim w klasach specjalnych, integracyjnych i ogólnodostępnych, Wyd. APS, Warszawa 2010. 